DOI: 10.15642/JIIS.2014.8.1.91-111

\title{
INDONESIAN SALAFISM ON JIHĀD AND SUICIDE BOMBINGS
}

\author{
Rusli \\ IAIN Palu - Indonesia | rusli_mochtar@yahoo.com
}

\begin{abstract}
This paper deals with jihäd and suicide bombings from the perspective of Indonesian salafism. It is argued that there are two different points of view related to this issue. The first is those who are affiliated with Wahhābi salafists such as those involved in Salafi-based foundations like As-Sunnah, Ihyaut Turats, al-Sofwah, Lajnah alKhairiyah, Lajnah al-Istiqamah, and Wahdah Islamiyyah. They do not agree with suicide bombing directed to Western targets-mainly America-and its symbols. Suicide bombings are equivalent to killing oneself, and this is extremely forbidden in Islam. The second is Salafijihädists who have justified suicide bombing attacks to infidel targets and the symbols of tagut (false god). The reason is blowing oneself is not the same as committing suicide, for suicide is a sin. However, he is believed as carrying out "martyrdom operations", sacrificing himself for the sake of the superior goal of defending his religion and community, while suicide is a hopeless deed performed by a person who kills himself for his own selfish reason.
\end{abstract}

Keywords: Indonesian salafism, jihad, suicide bombings, Wahhābi-salafism

\section{Introduction}

Salafism is seen as a social movement in the discourse of Islamic thought. From a sociological point of view, social movement may be studied from two considerable paradigms. The first paradigm is put forward by Ralph Turner and Lewis Killian, ${ }^{1}$ who divide social movement into three categories; first, value-oriented movement, in which the members have commitment to the principle of rejecting all

${ }^{1}$ Ralph Turner and Lewis Killian, Collective Behaviour (Englewood Cliffs, New Jersey: Prentice Hall, 1957). 
forms of compromise for sake of a desired goal; second, poweroriented movement, whose main goal is to seize power, status and recognition for the members of movement. One of the dogma of this movement is the assumption that by having control over economic and political power, anything deemed as evil in society can be wiped out; third, participation-oriented movement, which may take many forms such as passive-reform movement that only voices defects in society, but never tried to actively eradicate them, or personal-status movement that recommends a redefinition of an existing status system, by which their status is expected to be raised.

The second paradigm is proposed by David Aberle who divides social movement into transformative, reformative, redemptive and alternative. ${ }^{2}$ Transformative movement is a movement which aims at bringing about changes comprehensively for individuals or societies, which usually involve violence and destruction. Reformative movement is usually carried out to eradicate defects in an existing social system; however, it does not destroy its basic structure. Redemptive movement is a movement that is focused more on individual changes than institutional ones, while alternative movement makes an effort to partially alter an individual's behavior. This movement assumes that human beings are naturally good; however, it would be better if their bad characters and behavior are eradicated.

As a social movement, Salafism is not in an intellectual vacuum, but emerges in the environment surrounded by intellectual turbulences, and is based on a sturdy epistemological foundation. This following issue deals with an historical sketch of Salafism and its epistemological foundation on which this movement and its activities are based.

\section{The Brief History and Epistemology of Salafism}

The term "Salafism" contains two words "salaf" and "ism". The word "salaf" refers to "ancestors, predecessors,"3 while "ism" generally refers to "system of belief." " If combined, the word "Salafism" may

2 Cited in Frank N. Magill, International Encyclopedia of Sociology, Vol. 2 (London, Chicago: Salem Press, 1995), p. 1244; Gordon Marshall, Oxford Dictionary of Sociology, $2^{\text {nd }}$ Edition (Oxford, New York: Oxford University Press, 1998), p. 166.

3 Dictionary Composing Team, Kamus Besar Bahasa Indonesia, Third Edition (Jakarta: Balai Pustaka, 2005), p. 982.

${ }^{4}$ Ibid., p. 444. 
mean "system of belief that is based on the practice of pious ancestors or predecessors." The Arabic word describing this meaning is salafiyyah, while its advocates are called sala $\bar{i}$ (plural: salafiyyūn). ${ }^{5}$ In Arabic dictionaries, there are myriad of meanings attached to the word salaf. It may refer to "loan and payment in advance" (al-qard wa al-salam), "all activities carried out previously by someone" (kull 'amal qaddamabu al'abd), and "preceding nation in history" al-qawm al-mutaqaddimun fi alsayr). ${ }^{6}$ However, the most appropriate meaning in our discussion is the second and third meaning.

The difference of opinions occurs while discussing a technical meaning of the word salaf. It relates to the question whether the word salaf refers to a period of time or a particular method. Those who advocate the first meaning have different opinion on the specification of the period of salaf. According to Amir, al-Qayrawāni limits that period only to the Companions of the Prophet (Șahābah), Al-Ghazāil limits it only to the periods of Șahābah and Tábi ìn (a generation after Sahăbah), ${ }^{7}$ while Ibn Taymiyyah, al-Shawkāni, the majority of Muslim

5 The use of the word salafi is initially introduced by al-Sam'ani who states that salaf $\bar{i}$ is an attribution to the word salaf, and an adherence to this school. See 'Abd al-Karim ibn Muhammad al-Sam‘āini, al-Ansāb, Vol. 7 (Kairo: Maktabah Ibn Taymiyyah, 1976), p. 104.

${ }^{6}$ Arabic text is from the book Lisān al-'Arab, see Ibn Manzūur, Lisān al-'Arab, Vol. 4 (Kairo: Dār al-Hadith, 2003), p. 649; Sayyid Muhammad Murtadāa al-Husayni al-Zabidi,

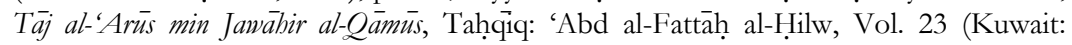
Maṭba'ah Hukūmah al-Kuwayt, 1986), pp. 454-55; Muhammad ibn Ya'qūb al-

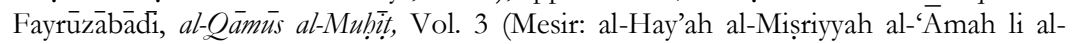
Kitāb, 1979), p. 149; al-Khalil ibn Aḥmad al-Farāhidī, Kitāb al-'Ayn, Tahqiqu: 'Abd alḤamid Handāwi, Vol. 2 (Beirut: Dār al-Kutub al-'Ilmiyyah, 2003), p. 265; Ismā̄il ibn

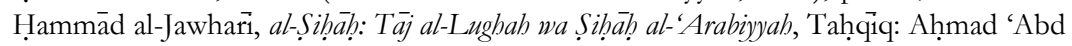
al-Ghafưr 'Atțār, Vol. 4 (Beirut: Dār al-'Ilm li al-Malāyin, 1979), p. 1376; Majma' alLughah al-'Arabiyyah, al-Mu'jam al-Wasit, 4th Edition (Mesir: Maktabah al-Shurūq alDawliyyah, 2004), p. 444. This word salaf $\bar{\imath}$ in the dictionary of al-Mujam al-Wasit is defined as "those who return to the Quran and Sunnah and invalidate other sources in

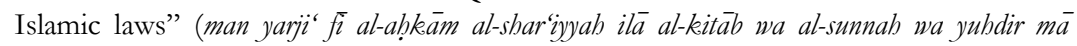
$\operatorname{siw} \bar{a} \bar{a}$.

7 Abū Hāamid Muḥammad al-Ghazāili, "Iljām al-'Awwām 'an 'Ilm al-Kalām," in

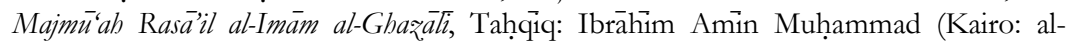
Maktabah al-Tawfiqiyyah, nd), p. 320. The text is as follows:

اعلم أن الحق الصريح الذي لا مر اء فيه عند أهل البصائر هو مذهب السلف, أعنى : الصحابة و التابعين 
scholars expands it to three periods such as Ṣahạabah, Tābi īin and Tăbi al-Täbi ín (a generation after Täbi ${ }^{\bar{T}}$ in). ${ }^{8}$ The reason for this limitation is more theological than sociological, because there is a hadith of the Prophet which states "The best people are those living in my generation, and then those who will follow them, and then those who will follow the latter."'

However, from sociological point of view, the term salaf is raised in the context of the struggle of thought in Islam. It happened during the caliphate of 'Abbasiyyah, in which an intellectual atmosphere and scientific environment was so widely open that it allowed the emergence of Islamic studies, scholarly debates, and writing of academic works. As the consequence, there emerged a diverse group of studies, which later became a school (madhhab, firqah). In its development, these schools established different methodological tendencies. Some scholars stick to mind reasoning, like Mu'tazilites and the philosophers, called as ashäb al-ra'y, while others insist on the text (nass.s), known as așäb al-hadith.

Both scholars have been in serious tension and conflict in the following years. Mutazilites neglected many Prophetic traditions and naql (narration), treated abl al-hadith unfairly, and denied them. They also did ta'wil (allegorical interpretation) of the allegedly ambiguous Qur'anic verses (mutashäbihatat), which is not acceptable among the scholars of abl al-sunnah. Otherwise, abl al-hadith often claimed as the followers of pious Salaf scholars from the generation of Companions and Täbi'in who relied on religious texts, as a counter-hegemony against the rationalist views of the philosophers and theologians widespread in the period of 'Abbasiyyah. However, since rationalist thought represented by the Mu'tazilites at that time was more

\footnotetext{
8 Jābir Idris 'A $\overline{l i}$ Amir, Manhaj al-Salaf wa al-Mutakallimin fì Muwāfaqab al-'Aql li al-Naql wa Athar al-Manhajayn fi al-'Aqidah, Vol. 1 (Riyàḍ: Aḍwà' al-Salaf, 1998), 36-37; See also, 'Isā ibn Nāṣir al-Darabi, "Min Ma'ālim al-Taysir fi Tafsir al-Salaf," Majallah al-Bubūth wa al-Dirasàt al-Qur'aniyyah, No. 3, Year II, pp. 163-164.

9 The text of the hadith: خير القزون قرني ثم الذين يلونهم ثم الذين يلونهم

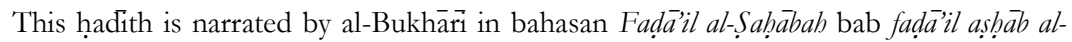
Nabì salla Allāb 'alayh wa sallam and Muslim in the chapter of Fada'il al-Saḅäbah (hadith no: $210,211,212$ ) through the narration of 'Abd Allăh ibn Mas'ud.
} 
dominant due to the support of power, then abl al-hadith's thought with its leading scholars, Ahmad ibn Hanbal, suffered from exclusion.

In addition to the issues of Islamic conquest and the conversion of the adherents of other faiths into Islam, the spread of heresy (zindiq) and the emergence of the people involved in spreading doubts, art of debate, and method of argumentation, to confuse Muslims and sow doubts on the understanding of Islamic theology, take part in strengthening Salafi's method and movement. These factors, according to the al-Butit, ${ }^{10}$ appeared at the last period of the Companions in a limited way, but began to expand and increase at the time of the expansion of Islamic conquest and the conversion of other faith's followers into Islam. It attracted the attention of Salafi scholarsamong them is Ahmad ibn Hanbal—and encouraged them to counter those influences in order that Islamic theology is not covered with cloud of doubt, delusions, and misleading thoughts. This especially happened in the reign of 'Abbāsiyyah.

Therefore, based on the above description it can be said that Salafism both as a movement and method emerged in the era Ahmad ibn Hanbal, when the 'Abbāsiyyah had been in power. Therefore, it is no exaggeration that Salafism is essentially a phenomenon of 'Abbasiyyah arising as a result of the Muslim's weaknesses in the face of the rationalist thinking of the philosophers and theologians, in addition to their attachment to the clear and simple religious texts. The majority of Muslim Arabs before the Islamic conquest are a modest society supported by a limited civilization. Nomadic environment (badawab) in which they lived resembles a plain sheet in the sense that they merely understand Islamic texts of the Quran and the Sunnah of the Prophet, without undertaking ta'wīl (allegorical exegesis) and qiyas (analogical reasoning). The modesty of life and the lack of structure and complexity in the Arabian Peninsula maintains the method adopted by them in understanding Islam, "textualist method" (al-nahj al-nususis $)$, which gives priority to the text over philosophy, and narrative (al-ma'thür) over qiyas. ${ }^{11}$

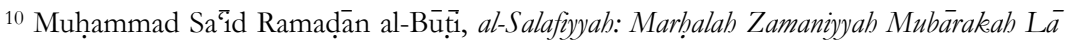
Madhhab Islämi (Damaskus: Dār al-Fikr, 1990), p. 35.

${ }^{11}$ Muhammad 'Imārah, al-Salafiyyah (Tunisia: Dār al-Ma'ärif, nd.), p. 9.
} 
The next scholar who is considered to be the most determined to defend Salafism is Ahmad Ibn Taymiyyah (d. 728/1328), whose framework of thought in the field of law and theology is the same as Ibn Hanbal. He became a main reference for any Salafi movement. In matters of faith, the principles should be drawn from the text, as well as legal issues. Intellect, from Ibn Taymiyyah's point of view, has no authoritative power, but only serves to reinforce the law, not create it. The function of reason is to bring narrative (manquid) closer to reason (ma'qu'), without having an authoritative power either to reject or accept it. ${ }^{12}$

In the contemporary era, there is a significant shift in terms of the methods and approaches to the understanding of religious texts. If the Salafi movement seemed previously so rigid in their understanding of Islam, but in the contemporary era, Salafi movement shows something fresh, although the issue of monotheism is relatively not different. This condition cannot be separated from the role of important figures such as Jamāl al-Dīn al-Afghāni and Muhammad 'Abduh. Both figures are considered as the early pioneers and founders of the modern Salafi movement at the end of the 19th century.

The idea of modern Salafi is based on some of the following goals (1) To purify Islam from all forms of innovation (bid'ab) that can affect its purity based on the Quran and Sunnah; (2) To free Islamic law from blind imitation of traditional schools of Islamic jurisprudence; (3) To perform ijtihäd as the best media to bridge the gap between historical Islam and modernity; (4) To introduce a modern education system which reconciles the religious and secular sciences; and (5) To revive Arabic linguistics in order to facilitate the interpretation of the authentic Islamic sources (Quran and Sunnah). ${ }^{13}$

In the later development, the Salafi movement is different to a great deal from what reformers echoed. Riḍā's views later gain a place among the extreme-right group. Influential figures who echoed Riḍ̄as views include Hasan al-Bannā and Sayyid Qutb. Both of these figures have a number of the same principles. Both saw Islam as a

\footnotetext{
12 Sayyid 'Abd al-'Aziz al-Sili, al-'Aqìdah al-Salafiyyah bayn al-Imām Ibn Hanbal wa al-Imām Ibn Taymiyyah (Kairo: Dār al-Manār, 1993), p. 272.

13 Ahmed Ibrahim Abushouk, "Al-Manār and the Hadhrami Elite in the MalayIndonesian World: Challenge and Response," JRAS, Series 3, Vol. 17, No. 3 (2007), p. 304.
} 
comprehensive system that provides a range of guidance for all areas of life. Both identified their interpretation of Islam with Islam itself, and believed that alternative readings are not valid. Both did not believe in reason, and prioritized actions over thoughts. Both have the same view of what is required by the Islamic government in the future. Finally, they regarded violence as a legitimate medium for establishing Islamic order that they missed. ${ }^{14}$

Islamic government is considered as an integral part of Islam, and is essential to ensure the implementation of shariah. The model that should be followed is that was once epitomized by the Prophet and the Guided Chalips (al-kbulafä' al-räshidūn). Al-Bannā assumed that the Companions as noble knights who runs jihad not for worldly interests or personal ambition, but to guide them to the path of Islam, while Qutb stated that the Companions are God's chosen servants to show humanity as a model that should be followed. ${ }^{15}$

According to these two scholars, all existing political systems have failed. Neither capitalist nor socialist systems are able to provide moral and spiritual values human beings need. As a result, the Western world has immersed in a variety of mental illnesses, sexual impropriety, and moral degradation. Therefore, the world needs Islam. The strategies to bring about these changes, according to al-Bannā, is to preach by way of the indoctrination of the masses-from individuals to families, societies, government, and the last, the world in general. ${ }^{16}$ Meanwhile, according to Qutb, preaching is not enough. Jihäd is important to protect the Islamic mission (dawab) and eliminate the physical and mental barriers that prevent a person to be a true Muslim. ${ }^{17}$ However, in the case of those who do not accept such propaganda, al-Bannā asserted that Islam emphasizes being kind to minorities and confirmed that establishing peaceful relationships with them is possible. However, al-Bannā insists that Muslims must wage jihad until all people say "there is no god but Allah and Muhammad is his messenger," and

\footnotetext{
14 Ana Belén Soage, "Hasan al-Bannāa and Sayyid Quṭ: Contiunity or Rupture?" The Muslim World,Vol. 99, no. 2 (April 2009), p. 295.

15 Ibid., p. 300.

16 Ibid., pp. 302-3.

${ }^{17}$ Ibid., pp. 303-304.
} 
fighting the Jews and Christians is an obligation that brings multiple rewards from God. ${ }^{18}$

Some important principles contained in al-Bannā's wiritngs is supported by radical Islamic groups. One example that might represent this is the al-Bannā's view on jibäd, which is considered as one of the pillars of Islam. Jihäd, in al-Bannā's view, is a "military struggle." 19 The idea was the main argument for the treatise of al-Faridah al-Gha'ibah (the Lost Obligation), an influential pamphlet written by 'Abd al-Salam Faraj, drafting organizational ideology that once killed Anwar Saddat in October 1981. Various radical movements in the following modern era have been basically influenced by such figures as Ḥassān al-Bannā dan Sayyid Quṭ.

\section{Indonesian Salafism on Jihād and Suicide Bombings}

\section{Wahhābi-Salafism}

In Indonesia, there is a variety of Salafism. However, the most salient in the discourse of Salafism is Salafi-Wahhabism and SalafiJihadism. Salafi-Wahhabism is known as a sect in Islamic movements which is related to its main figure, Muhammad ibn 'Abd al-Wahhāb and his advocates such as 'Abd al-'Aziz ibn Bāz and Muḥammad Șalih al-'Uthaymin. These figures are known as purists promoting literalism in understanding Islamic texts. As the name suggests, the "purists" are primarily concerned with maintaining the purity of Islam as outlined in the Qur'an, Sunna, and consensus of the Companions. They believe that the primary emphasis of the movement should be promoting the Salafi creed and combating deviant practices, just as the Prophet fought polytheism, human desire, and human reason.

This movement is seen as anti-rationalism, anti-intellectualism, anti-mysticism, and strict literalism, which is hostile to humanistic epistemology, and attempts to interpret the Divine law without any degree of contextualization, thereby proclaiming 'the diacritical and indeterminate hermeneutic of classical jurisprudential hermeneutic as

\footnotetext{
18 Ibid., p. 304.

${ }^{19}$ Ḥasan al-Bannā, "Risālah al-Jihād" in Majmū'ab al-Rasā'il al-Imām al-Shabìd Hasan alBannā (Alexandria: Dār al-Da’wah, 1998), pp. 263, 279.
} 
corruptions of purity of Islamic faith and law'.20 This oppositional dialectic and hostility extends not only to the 'Western Other' but also to un-likeminded Muslims. In its self-contained system of belief 'it has no reason to engage or interact with the other except from the point of dominance'. ${ }^{21}$

In Indonesia, this Salafi movement grew in campuses. Since 1900s, this movement got new impetus from the arrival of the graduates from Middle East and veterans from Afghanistan, including Ja'far Umar Thalib, Yazid Abdul Qadir Jawwas, Yusuf Usman Baisa, Muhammad Yusuf Harun, Ahmad Zawawi and M. Zaitun Rasmin. ${ }^{22}$ Their efforts to carry out Salafi missionary activities in turn make Salafi communities come to surface in many cities and areas in Indonesia. The far-reaching growth of this kind of community has produced Salafi-based foundations such as As-Sunnah, Ihyaut Turats, al-Sofwah, Lajnah alKhairiyah, Lajnah al-Istiqamah, and Wahdah Islamiyyah. The attention of donor foundations in Saudi Arabia and other Gulf nations to support Salafi missionary activities after the Gulf War in 1990 has facilitated this growth. In line with the mushroom-like growth of Salafi foundations, there emerge Salafi madrasabs in many areas of Indonsia (See the table 1).

These Salafi madrasabs in Indonesia, Hasan argued, ${ }^{23}$ took the model of Islamic learning centre associated with Muqbil ibn Hādi alWadi ${ }^{\bar{i}},{ }^{24}$ one of the most outstanding Salafi scholars in Yemen. The

${ }^{20}$ Cited in Adis Duderija, "Islamic Groups and their World-views and Identities: NeoTraditional Salafis and Progressive Muslims," Arab Law Quarterly, Vol. 21 (2007), p. 349.

${ }^{21}$ Ibid., pp. 349-350.

22 Noorhaidi Hasan, "Salafi Madrasabs and Islamic Radicalism in Post-New Order Indonesia," in Kamaruzzaman Bustaman-Ahmad and Patrick Jory (eds), Islamic Studies and Islamic Education in Contemporary Southeast Asia (Malaysia: Yayasan Ilmuan, 2011), p. 95 .

23 Ibid., p. 105.

${ }^{24}$ Muqbil began to receive recognition as a leading Salafi figures in the early 1980s due to various efforts to spread Salafi missionary movement in Yemen. His knowledge of the Wahhabi teachings was strengthened from his experiences of studying in Saudi Arabia for nearly two decades. At first, he studied in the Islamic teaching center in Najran, Mecca, hold by Muhammad ibn Șălih al-'Uthaymin, before getting enrolled in the Islamic University of Madinah. During his studies, he had the opportunity to attend academic circles of the most important Salafi figures, such as 'Abd al-'Aziz ibn Bāz dan Muhammad Nạsir al-Dīn al-Albāni. He was arrested for his alleged 
teachers in these madrasabs are graduates from this centre of Islamic learning. If not, they were graduated from the universities in Saudi Arabia controlled by Saudi's religious scholars, mainly Muhammad ibn Sălih al-'Uthaymin. This teachers' relation to the mentors from the Middle East is closely maintained. They maintain this relationship through correspondence, telephone, and fax machine, particularly when they feel necessary to ask questions or request legal opinions (fatwa) to deal with complicated issues.

Table 1: Salafi-Wahabism-based Pesantrens in Indonesia

\begin{tabular}{ll}
\hline \multicolumn{1}{c}{ Area } & \multicolumn{1}{c}{ Name of Pesantren } \\
\hline Yogyakarta & Ihyaus Sunnah (1994); Bin Baz; al-Ansar; Difa' Anis Sunnah \\
Solo & Al-Madinah dan Imam Bukhari (1995-2000); Ibn Taimiyah \\
Magelang & Minhajus Sunnah \\
Semarang & Lu'lu' wal Marjan \\
Cirebon & As-Sunnah \\
Temenggung & Al-Athariyah \\
Sukoharjo & Ittiba'us Sunnah \\
Magetan & Ittiba'us Sunnah \\
Jember & Al-Salafy \\
Ngawi & Ta'zimus Sunnah \\
Gresik & Al-Bayyinah \\
Cilacap & Al-Furqan \\
Pekanbaru & Al-Furqan \\
Makasar & As-Sunnah \\
Balikpapan & Ibn Qayyim \\
\hline
\end{tabular}

Source: Noorhaidi Hasan, "Salafi Madrasabs and Islamic Radicalism in PostNew Order Indonesia," in Islamic Studies and Islamic Education in Contemporary Southeast Asia (Malaysia: Yayasan Ilmuan, 2011), pp. 9899.

One of the Salafi figures in Indonesia who had been influenced in a great deal by a great Yemeni salafi scholar, Muqbil ibn Hādi alWādicí, is Ja'far Umar Thalib. He widened his knowledge on Salafi teachings by studying with al-Wädi $\bar{i}$ in Yemen. He also learned from other Salafí-Wahhābi scholars through his hạj to Mecca and Medina. Whenever he visited two holy cities, he took the chance to broaden his knowledge of Salafi ideas by attending religious lectures given by prominent Saudi Salafî-Wahhābi teachers, such as Muḥammad Nașir

involvement in a coup d'etat against the sacred mosque led by Juhayman al-'Utaybi. After his release from the prison for several months, he returned to his homeland. 
al-Dìn al-Albāni and 'Abd al-'Aziz ibn Bāz. Thalib's encounter with Muqbil and other Salafî-Wahhābi ulamas refreshed and strengthened his ideas and commitment to the movement that he initially developed in Indonesia. To transfer his salafi ideas, he established his own pesantren (traditional Islamic education institution) named Ihyăà alSunnah (Preserving the Prophet's Tradition).

Ja'far Umar Thalib has the same opinion as other Salafists that jibäd is an obligation to every Muslim. He prescribes certain limits on and requirements for the compulsion to commit oneself to jibäd. He quoted Ibn Qayyim al-Jawziyyah, while distinguishing four categories of jiha $\bar{d}$, the struggle against the self (jiha $\bar{d}$ al-nafs), the struggle against the evil (jihäd al-shaytān), the struggle against non-believers and hypocrites (jibäd al-kuffar wa al-munäfiqin) and the struggle jibä arbāb alzulm wa al-bid'ah (war against despotism and heresy). ${ }^{25}$ He argues that what is intrinsic in jibäd is a struggle to be consistent in keeping to the straight path, identical with the jihäd of the first category. But the situation in the Moluccas demands Muslims wage a jibäd of the third category, namely jïhäd al-kuffar wa al-munäiqin. This category is still divided into two: jihäd al-talab or jihäd al-bujum and jïhäd al-mudäfa'ah. In a jibä al-talab, one in which the offensive is taken, Muslims initiate an attack on infidels by offering them three choices: converting to Islam; paying a poll tax; or being subject to war. This sort of jibäd is controlled by a host of regulations. For example, it can be carried out only under the command of a ruler (imäm) whose legitimacy and leadership are approved by Muslims. In addition, it should be conducted under a strict ethical code; women and children are not allowed to be the targets of attacks. The jïhäd al-mudäfa' $a b$ is a defensive action, when Muslims are under attack by infidels. While the first jibäd is categorized as a fard kifayah, the second one is a fard 'ayn. ${ }^{26}$

However, regarding suicide bombings, Thalib argues that it is religiously illegitimate to carry out suicide operations. It can be inferred from this position as a main protagonist of Sururi groups, including

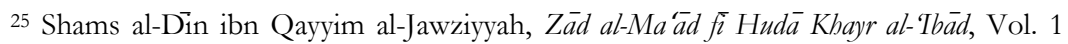
(Cairo: Mustafāa al-Bābi al-Halabi, 1970), pp. 39-40; See also Noorhaidi, Laskar Jihad: Islam, Militancy and the Quest for Identity in Post-New Order Indonesia (Unpublished Ph.D Thesis, Universiteit Utrecht, 2005), p. 154.
}

${ }^{26}$ Noorhaidi, Laskar Jihad, p. 154. 
Salmān al-'Awdah, Șafar al-Ḥawāili, Aymān al-Ẓawāhirí, 'Abd Allāh 'Azzām, Osama bin Laden, and Mullah 'Umar, ${ }^{27}$ who are responsible for the spread of violence, radicalism and intolerance among youth of the country, ${ }^{28}$ and to some extent agreed with suicide attacks. Those who have been involved in Salafi-based foundations like As-Sunnah, Ihyaut Turats, al-Sofwah, Lajnah al-Khairiyah, Lajnah al-Istiqamah, and Wahdah Islamiyyah, also has the same opinion as other Wahhābi salafists. They do not agree with suicide bombing especially directed to Western targets-mainly America — and its symbols. They adopted the view of Muḥammad ibn Ṣălih ibn al-'Uthaymin concerning attacking an enemy by blowing oneself up. When al-'Uthaymin was asked the question "What is the ruling regarding acts of jibäd by means of suicide, such as attaching explosives to a car and storming the enemy, whereby he knows without a doubt that he shall die as a result of this action," he responded by saying, "Indeed my opinion is that he is regarded as one who has committed suicide, and as a result he shall be punished in hell, for that which is authenticated on the authority of the Prophet, "Indeed, whoever (intentionally) kills himself then certainly he will be punished in the fire of hell, wherein he shall dwell forever."29

Therefore, it is clear that the reason this salafi group put forward is that suicide bombings involve killing oneself, while suicide is strictly prohibited in Islam, according to the following hadith of the Prophet:

It is narrated on the authority of Abu Hurayrah that the Messenger of Allah (may peace be upon him) observed: He who killed himself with steel (weapon) would be the eternal denizen of the Fire of Hell and he would have that weapon in his hand and would be thrusting that in his stomach forever and ever, he who drank poison and killed himself would sip that in the Fire of Hell where he is doomed forever and ever; and he who killed himself by falling from

\footnotetext{
${ }^{27}$ Noorhaidi Hasan, "Ambivalent Doctrines and Conflicts in the Salafi Movement in Indonesia," in Roel Meijer (ed.), Global Salafism: Islam's New Religious Movement (London: Hurst \& Company, 2009), pp. 185-6.

28 Madawi Al-Rasheed, Contesting the Saudi State: Islamic Voices from A New Generation (New York: Cambridge University Press, 2007), p. 79.

${ }^{29}$ Cited in Shireen Khan Burki, 'Haram or Halal? Islamists' Use of Suicide Attacks as Jihad," Terrorism and Political Violence, Vol. 23 (2011), p. 589.
} 
(the top of) a mountain would constantly fall in the Fire of Hell and would live there forever and ever. ${ }^{30}$

In short, suicide attacks in the perspective of this salafi group are seen as un-islamic and strictly forbidden in Islam based on the sacred text.

\section{Salafi-Jihadism}

Salafi-Jihadism is a term coined by Gilles Kepel to describe the beliefs of Salafi who became interested in violent jihad starting in the mid-1990s. ${ }^{31}$ It refers to the movement which insists that violence is a legitimate tactic in the current social and political context in which the Muslim world finds itself. The aim is not just to destroy the enemy, but to torment and degrade it. What is distinctive about the jih $\bar{a} \bar{i}$ wing of Salafism is its fusion of the Salafi elements with an ethos of murderous violence_an ethos, to repeat, vehemently rejected by the Salafi mainstream.

Teachings of Salafi-jihadism had been around in Indonesia since the 1940s, even they were not called Salafi-jihadism. The group that promoted these teachings was Darul Islam (Abode of Islam), which wanted to establish an Islamic state in Indonesia. The movement, launched in West Java and led by Sekarmadji Maridjan Kartosuwirjo (a Javanese), was originally a cultural and language resistance initiative by the Sundanese. Filling the post-Independence power-vacuum in West Java at the end of 1940s, Kartosuwirjo and his supporters, the "Indonesian Islamic Soldiers (TII)," proclaimed the "Indonesian Islamic State" (NII). Hence, he openly defied not only the Dutch, but also the nationalist government in Jakarta. Subsequently, Darul Islam mushroomed in Aceh, Central Java, and South Sulawesi.

This spirit of jih $\bar{a} \bar{i}$ movement is continued by, first, Jamaah Ansharut Tauhid (JAT), established in 2008 by Abu Bakar Ba'asyir, the former head of Jemaah Islamiyah (Islamic Group). This group focuses on dakwah (proselytization among Muslims), participates in demonstrations, publishes a magazine, and does public outreach to spread Salafi-Jihadists ideas. It has clearly defined organizational structure, maintains regional branch offices down to the district and

\footnotetext{
30 Abū al-Husayn Muslim ibn al-Hajijaj al-Nisābūri, Sahịị Muslim, The Book of Faith (Kitāb al-İmān) (Saudi Arabia: Dār al-Afkār al-Dawliyyah, 1998), p. 69

31 Wikipedia, "Salafist-Jihadism," in http://en.wikipedia.org/wiki/Salafist jihadism. Accessed on 19 January 2014.
} 
cell levels in areas where it has taken root, and has a paramilitary with that conducts training exercises. This group argued that jibäd in Indonesia is absolutely fard 'ayn (individual obligation); therefore, no person or organization can prevent someone to carry out jibàd.

However, there is a controversy about Abu Bakar Ba'asyir regarding his opinion of suicide operation carried out by some people in Indonesia. Some people believed that Ba'asyir supported this kind of operation since he was a part of Jemaah Islamiyah and its alleged spiritual head in Indonesia, ${ }^{32}$ while in some media Ba'asyir argued that no Islamic law could justify an attack that injured many innocent people. Furthermore, he insisted that bomb attacks are an accursed act, sinful, except to those people proven to have attacked Muslims. ${ }^{33} \mathrm{He}$ said that suicide bombing that occurred in Cirebon is an illegal act prohibited by Islam. ${ }^{34} \mathrm{He}$ also strongly denied police allegations that the recent Surakarta church suicide bomber Pino Damayanto was affiliated with his organization. In his book, Ba'asyir argued that suicide is wrong and forbidden but istishbäd (the search for martyrdom) is not and that recent bombing events were such practices, although he regrets that they were conducted in a safe zone. ${ }^{35}$

Second, Jemaah Islamiyah (Islamic group), a clandestine Salafi Jihadist movement that arose in 1993 as a breakaway faction of Darul Islam (DI). This Salafi-jihadist combined the textual literalism of Salafi Islam with the belief that violent jibäd is the best way to achieve one's goals. "Darul Islam" (DI) is the umbrella term used to refer to several regional Islamic rebellions that fought against the Indonesia army in

\footnotetext{
32 Dian Intannia, "Ba'asyir Restui Bob Natal”, detik.com (29 October 2002); Editorial Team, "Laporan Utama," Gatra (8 May 2004); also see International Crisis Group, "Indonesia Backgrounder: How The Jemaah Islamiyah Terrorist Network Operates," Asia Report, No. 43 (11 December 2002); Adrianus Harsawaskita and Evan A. Laksmana, "Rethinking Terrorism in Indonesia: Lesson from The 2002 Bali Bombing," UNISCI Discussion Papers, No. 15 (October 2007), p. 68.

33 "Bombing forbidden in Islam, Ba'asyir says," The Jakarta Post (Monday, 03 October 2011) in http://www.thejakartapost.com/news/2011/10/03/bombing-forbidden-islam-baasyir-says.html-0. Accessed on 28 April 2014.

${ }^{34}$ Editorial Team, "Ba'asyir Kutuk Bom Cirebon” (15 April 2011), in http://nasional.news.viva.co.id/news/read/215075-ba-asyir-kutuk-bom-cirebon. Accessed on 28 April 2014.

35 Abu Bakar Ba'asyir, Catatan Dari Penjara: Untuk Mengamalkan dan Menegakekan Dinul Islam (Depok: Penerbit Mushaf, 2006), pp. 281-283.
} 
the 1950s before being crushed in the early 1960s. During Suharto's New Order regime, Darul Islam remained an underground movement. In the course of history, people associated with Darul Islam have conducted most of the violence in the name of Islam in Indonesia, including attacks in 1970s and 1980s. Bali bombing that occurred on 12 October 2002 was allegedly carried out by Jemaah Islamiyah, a splinter group of Darul Islam.

One of the Indonesian Salafi-jihadists, who was convicted as an actor behind Bali bombing and finally sentenced to death, is Imam Samudra. He has his own opinion about jihäd. He argues that jihäd today is not just obligatory but a fard 'ayn (personal obligation) upon every single Muslim. This is because the classical Muslim scholars ruled that if an inch of a Muslim's land is seized then it become incumbent to all Muslims to liberate it through armed jibäd. In today's context, Imam Samudra argues that there are plenty of Muslim lands that remain occupied by non-Muslims such as Palestine, Iraq, Afghanistan, Chechnya, Kashmir, and Mindanao. Because people of the respective lands are not able to repel the enemy by themselves, Muslims all over the world are to render their hands and participate in jibäd against the occupying forces. ${ }^{36}$

In Samudra's thought, jihäd is understood in the frame of revenge. It is based on the fact that the unbelievers or infidels have attacked Muslims without any limits. Therefore, Muslims are obliged to take revenge by waging war on them. According to Samudra, jibäd from the shari'ah perspective means "waging war" on the infidels who fight against Islam and Muslims. He called this concept as jibäd fĭ sabì Alläh (waging a holy war in the cause of Allah). ${ }^{37}$ In his opinion, the first Quranic verse on jibad that was revealed to the Prophet Muhammad is about waging war on the unbelievers who fight against Islam; that is, "And fight in the cause of Allah against those who fight against you, but do not transgress. Surely, Allah loves not the transgressors" (QS. al-Baqarah [2]: 191). War in the military history of Islam against Rome and Persia is based on the ethics of war which bans unlimited aggression; that is, a prohibition of killing women, children, elderly people, plants, and environment. ${ }^{38}$

\footnotetext{
36 Imam Samudra, Aku Melawan Teroris (Solo: Jazera, 2004), pp. 159-170.

${ }^{37}$ Ibid., p. 108.

${ }^{38}$ Ibid., pp. 115-116.
} 
In Samudra's view, if the infidels do not transgress in war, the ethics of Islamic war proceeds on the shari'ab path. As long as Americans, Jews, and their allies do not fight against and massacre Muslim civilians, so the Muslim fighters (mujahidin) have to wage war on them based on the original principle, that is, the prohibition of fighting against civil citizens. In fact, Americans and their allies always slaughter civilians in Muslim countries without any mercy. It is this background that brings about Samudra's jihädic concept of revenge; war for a war, blood for blood, massacre for a massacre, and so forth. Therefore, a series of bombing attacks emerged in some areas, such as suicidal bombing of Legian Bali on 12 October 2014.

Imam Samudra chose Bali as a target of attack, particularly Paddy's Bar and Sari Club, because they were places of vices. They have no value in Islam. Therefore, they can be put into "waste." Bali is also claimed as used as a place of spreading apostasy among Muslims. Therefore, this attack is legitimate. He justifies his argument by quoting the verse that says, "And slay them wherever you may come upon them." (QS. Al-Baqarah [2]: 191). ${ }^{39}$ The rationale behind Bali martyr's bombing is that it is considered as a fight against a hostile enemy in revenge for the death of Muslim civilians and jibäd in the path of Allah. ${ }^{40}$ Imam Samudra rejects the use of the word "suicide" for such an operation. Instead, he prefers to name it as "amaliyyat istishbadiyyah (martyrdom operation), a term that is popularly used by those who permit or support such an act. ${ }^{41} \mathrm{He}$ considers such an act to be an act of jibàd carried out by a sincere individual in pursuit of martyrdom enjoined by Islam.

In this case, the reference of Imam Samudra is Muslim scholar, Ibn Nuhāas, who cited 16 hadiths (the Prophet's tradition) about acts of individuals attacking an enemy's army singlehandedly disregarding his own safety, which could be considered as suicidal. Imam Samudra then provides an explanation given by Abū Hurayrah and Abū Ayyūb alAnșāi (both were companions of the Prophet) to put things in proper perspective. He reports that Abū Hurayrah, when asked to comment on such incidents, read the following verse aloud, "But there is [also] a

${ }^{39}$ Cited in Muhammad Haniff bin Hassan, "Imam Samudra's Justification for Bali Bombing," Studies in Conflict \& Terrorism, Vol. 30 (2007), pp. 1040.

40 Samudra, Aku Melawan Teroris, p. 188.

${ }^{41}$ Ibid., pp. $175-184$. 
kind of man who would willingly sell his own self in order to please God. .." (QS. Al-Baqarah [2]: 207).

When eyewitnesses of such incidents commented, "the person has thrown himself into destruction," Abū Ayyūb al-Anșāri corrected them by explaining that the following verse does not refer to such incidents, "And spend [freely] in God's cause, and let not your own hands throw you into destruction; and persevere in doing good: behold, God loves the doers of good" (QS. Al-Baqarah [2]: 195). Instead, the verse corrected those Muslims who felt that because God had made Islam victorious and the number of believers had increased over the years it would be prudent if they now spent their time in managing the economy. ${ }^{42}$

Imam Samudra points out that "the destruction" specified by the verse was a result of involvement in economic activities at the expense of jihäd. To him, the suicide operation (istishbäd) is legitimate, and concluding from what Ibn Nuhạs had written, is strongly encouraged. Samudra's view on this issue is the same as the view of other global Jihadi-Salafists who claimed "martyr" (shahid) for those who carry out suicidal operation. In this case, Jihadi-Salafists point out that the Quran recognizes and venerates the category of the martyr in verses 2:207, 3:169, 4:69, 4:74, 4:95-96 and 9:20-22.43 The two most cited verses, however, are:

Allah hath purchased of the believers their persons and their goods; for theirs (in return) is the garden (of Paradise): they fight in His cause, and slay and are slain: a promise binding on Him in truth ..." (QS. al-Tawbah (9): 111).

And call not those who are slain in the way of Allah 'dead.' Nay, they are living, only ye perceive not. (QS. al-Baqarah (2): 154).

In short, it can be argued that this group have justified the practice of suicide attacks or "martyrdom operations" targetted to symbols of tagüt (false god). Even, preeminently, the bombers are referred to as "martyrs" (shubadā) or "those who sacrifice themselves" (fidä'iyyün).

42 Cited in Muhammad Haniff, "Imam Samudra's Justification for Bali Bombing," p. 1042.

43 See Mohammed M. Hafez, "The Alchemy of Martyrdom: Jihadi Salafism and Debates over Suicide Bombings in the Muslim World," Asian Journal of Social Science, Vol. 38 (2010), p. 37. 
These men and women who "blow themselves up" or carry out "martyrdom operations" ("amaliyyat istishbädiyyah), do not commit suicide for suicide is a sin. This is because the shabid (martyr) has sacrificed himself for the sake of the superior goal of defending his religion and community, while common suicide is a hopeless deed performed by a person who kills himself for his own selfish reasons.

\section{Conclusion}

This paper is to analyze Indonesian Salafism on jïhäd and suicide bombings. From the discussion, it can be concluded that there are two different points of view related to this issue. The first is those who do not agree with suicide bombing directed to Western targets-mainly America - and its symbols. This is represented by Salafists who are involved in Salafi-based foundations like As-Sunnah, Ihyaut Turats, alSofwah, Lajnah al-Khairiyah, Lajnah al-Istiqamah, and Wahdah Islamiyyah. The reason is that the act of suicide bombings is the same as killing oneself, and this is extremely forbidden in Islam.

The second is those who have justified suicide bombing attacks to infidel targets and the symbols of tag $\bar{u}$ (false gods). The reason includes that the people who blow themselves up do not commit suicide for suicide is a sin, but they carry out "martyrdom operations" ('amaliyyat istishbädiyyah). Shabid (martyr) has sacrificed himself for the sake of the superior goal of defending his religion and community, while common suicide is a hopeless deed performed by a person who kills himself for his own selfish reasons. []

\section{References}

\section{Books and Articles}

'Imārah, Muhammad. al-Salafiyyah. Tunisia: Dār al-Ma’àrif, nd.

Abushouk, Ahmed Ibrahim. "Al-Manār and the Hadhrami Elite in the Malay-Indonesian World: Challenge and Response." JRAS. Series 3. Vol. 17. No. 3 (2007), pp. 301-322.

al-Bannā, Ḥasan. "Risālah al-Jihād." in Majmüah al-Rasàil al-Imām alShahìd Hasan al-Bannā. Alexandria: Dār al-Da’wah, 1998.

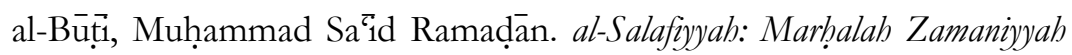
Mubärakah Là Madbhab Islämì. Damaskus: Dār al-Fikr, 1990. 


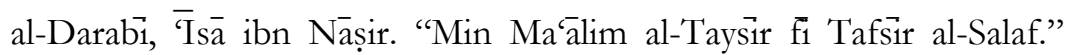
Majallah al-Buḅ̂th wa al-Dirasăt al-Qur'aniyyah. No. 3, Year II, pp. 163-164.

al-Farāhìì, al-Khalil ibn Aḥmad. Kitāb al-'Ayn. Taḥqiq: 'Abd al-Ḥamid Handāwì. Vol. 2. Beirut: Dār al-Kutub al-'Ilmiyyah, 2003.

al-Fayrüzābādi, Muhammad ibn Ya'qūb. al-Qāmūs al-Mubịt. Vol. 3. Mesir: al-Hay'ah al-Mișriyyah al-'Āmah li al-Kitāb, 1979.

al-Ghazāili, Abū Hāamid Muhammad. "Iljām al-'Awwām 'an 'Ilm al-

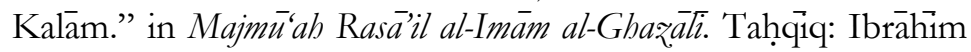
Amin Muhammad. Kairo: al-Maktabah al-Tawfiqiyyah, nd.

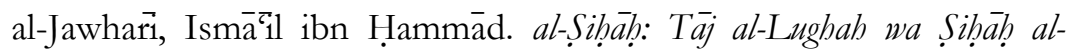
'Arabiyyah. Taḥqiq: Aḥmad 'Abd al-Ghafür 'Aț̣ār. Vol. 4. Beirut: Dār al-'Ilm li al-Malayin, 1979.

al-Jawziyyah, Shams al-Dīn Ibn Qayyim. Zäd al-Ma'ád fí Hudā Khayr al'Tbäd, Vol. 1. Cairo: Musțafā al-Bābi al-Ḥalabì, 1970.

al-Nisābūri, Abū al-Ḥusayn Muslim ibn al-Hajiàj. Sahị̄ Muslim. The Book of Faith (Kitāb al-Imān). Saudi Arabia: Dār al-Afkār alDawliyyah, 1998.

Al-Rasheed, Madawi. Contesting the Saudi State: Islamic Voices from A New Generation. New York: Cambridge University Press, 2007.

al-Sam‘āini, 'Abd al-Kāìm ibn Muhammad. al-Ansāb. Vol. 7. Kairo: Maktabah Ibn Taymiyyah, 1976.

al-Siili, Sayyid 'Abd al-'Aziz. al-'Aqìdah al-Salafiyyah bayn al-Imām Ibn Hanbal wa al-Imām Ibn Taymiyyah. Kairo: Dār al-Manār, 1993.

al-Zabidi, Sayyid Muhammad Murtad̄ā al-Husaynī. Täj al-'Arùs min Jawāhir al-Qämìis. Tahqiqu: 'Abd al-Fattāh al-Ḥilw. Vol. 23. Kuwait: Matba'ah Hukūmah al-Kuwayt, 1986.

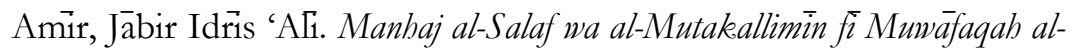
'Aql li al-Naql wa Athar al-Manbajayn fì al-'Aqïdah. Vol. 1. Riyāạ: Aḍwā' al-Salaf, 1998.

Ba'asyir, Abu Bakar. Catatan Dari Penjara: Untuk Mengamalkan dan Menegakkan Dinul Islam. Depok: Penerbit Mushaf, 2006.

Burki, Shireen Khan. "Haram or Halal? Islamists' Use of Suicide Attacks as "Jihad." Terrorism and Political Violence. Vol. 23 (2011), pp. 582-601.

Dictionary Composing Team, Kamus Besar Bahasa Indonesia. Third Edition. Jakarta: Balai Pustaka, 2005. 
Duderija, Adis. "Islamic Groups and their World-views and Identities:Neo-Traditional Salafis and Progressive Muslims." Arab Law Quarterly. Vol. 21 (2007), pp. 341-363.

Hafez, Mohammed M. "The Alchemy of Martyrdom: Jihadi Salafism and Debates over Suicide Bombings in the Muslim World." Asian Journal of Social Science. Vol. 38 (2010), pp. 364-378.

Harsawaskita, Adrianus and Evan A. Laksmana. "Rethinking Terrorism in Indonesia: Lesson from The 2002 Bali Bombing." UNISCI Discussion Papers, No. 15 (October 2007).

Hasan, Noorhaidi. "Ambivalent Doctrines and Conflicts in the Salafi Movement in Indonesia." in Roel Meijer (Ed), Global Salafism: Islam's New Religious Movement. London: Hurst \& Company, 2009.

Hasan, Noorhaidi. "Salafi Madrasabs and Islamic Radicalism in PostNew Order Indonesia." in Kamaruzzaman Bustaman-Ahmad dan Patrick Jory (eds). Islamic Studies and Islamic Education in Contemporary Southeast Asia. Malaysia: Yayasan Ilmuan, 2011.

Hassan, Muhammad Haniff bin "Imam Samudra's Justification for Bali Bombing," Studies in Conflict \& Terrorism, Vol. 30 (2007), pp. 1033-1056.

Intannia, Dian. "Ba'asyir Restui Bob Natal." detik.com. (29 October 2002).

International Crisis Group. "Indonesia Backgrounder: How The Jemaah Islamiyah Terrorist Network Operates." Asia Report, No. 43 (11 December 2002).

Magill, Frank N. International Encyclopedia of Sociology. Vol. 2. London, Chicago: Salem Press, 1995.

Majma' al-Lughah al-'Arabiyyah. al-Mu'jam al-Wasit. $4^{\text {th }}$ Edition. Mesir: Maktabah al-Shurūq al-Dawliyyah, 2004.

Manzūur, Ibn. Lisān al-'Arab. Vol. 4. Kairo: Dār al-Hadìth, 2003.

Noorhaidi, Laskar Jihad: Islam, Militancy and the Quest for Identity in PostNew Order Indonesia (Ph.D Thesis, Universiteit Utrecht, 2005).

Samudra, Imam. Aku Melawan Teroris. Jazera: Solo, 2004.

Soage, Ana Belén. "Ḥasan al-Bannā and Sayyid Quṭb: Contiunity or Rupture?" The Muslim World. Vol. 99. no. 2 (April 2009), pp. 294-311.

Editorial Team, "Laporan Utama," Gatra (8 May 2004).

Turner, Ralph and Lewis Killian. Collective Behaviour. Englewood Cliffs, New Jersey: Prentice Hall, 1957. 
Wikipedia. "Salafist-Jihadism." in http://en.wikipedia.org/wiki/Salafist jihadism. Accessed on 19 January 2014.

Editorial Team, "Bombing forbidden in Islam, Ba'asyir says," The Jakarta Post (Monday, 03 October 2011) in http://www.thejakartapost.com/news/2011/10/03/bombing-forbidden-islambaasyir-says.html-0. Accessed on 28 April 2014.

Editorial Team, "Ba'asyir Kutuk Bom Cirebon" (15 April 2011), in http://nasional.news.viva.co.id/news/read/215075-ba-asyirkutuk-bom-cirebon. Accessed on 28 April 2014. 